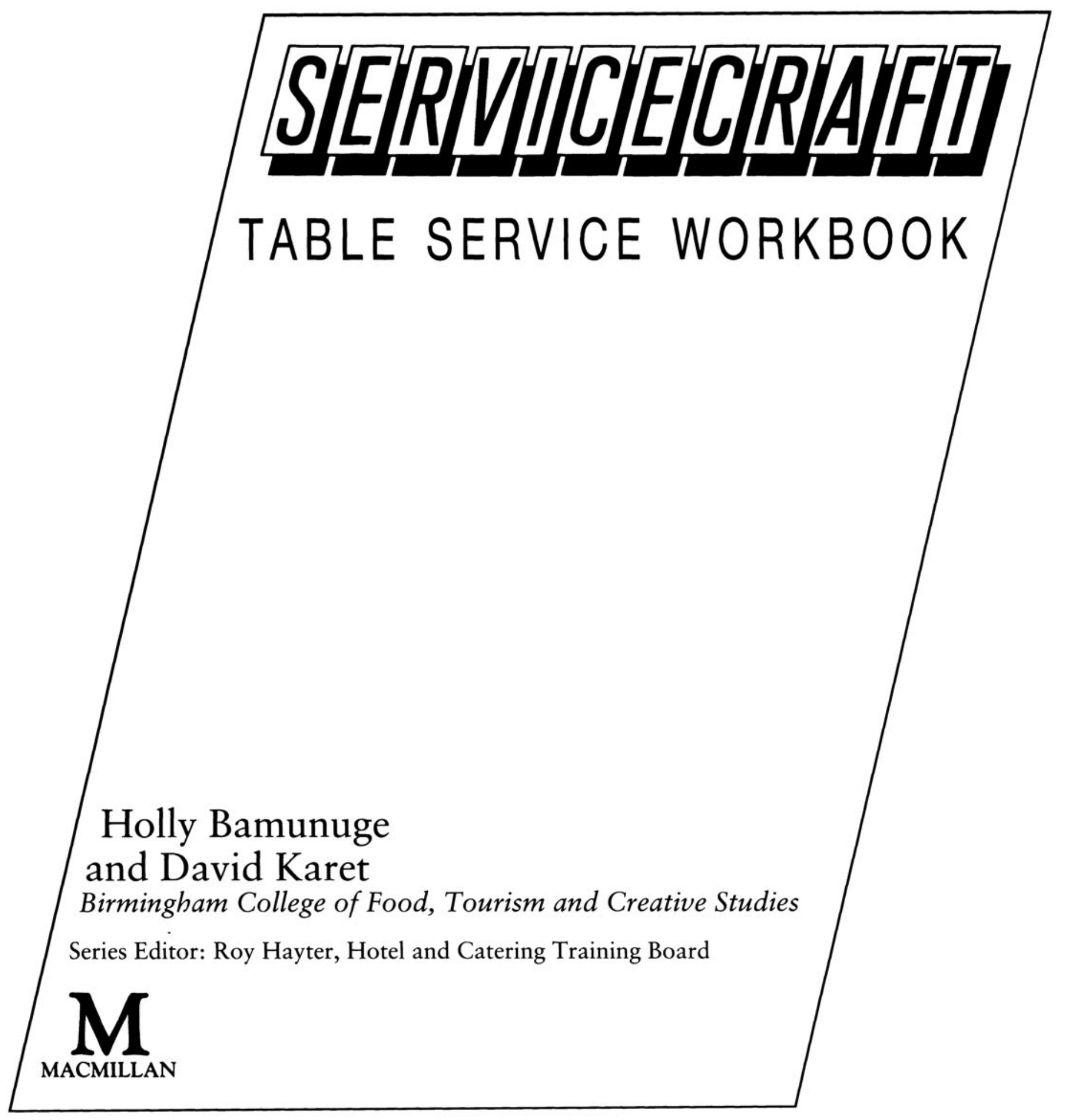


(C) Hotel and Catering Training Board 1988

All rights reserved. No reproduction, copy or transmission of this publication may be made without written permission.

No paragraph of this publication may be reproduced, copied or transmitted save with written permission or in accordance with the provisions of the Copyright Act 1956 (as amended), or under the terms of any licence permitting limited copying issued by the Copyright Licensing Agency, 33-4 Alfred Place, London WC1E 7DP.

Any person who does any unauthorised act in relation to this publication may be liable to criminal prosecution and civil claims for damages.

First published 1988

Reprinted 1989

Published by

MACMILLAN EDUCATION LTD

Houndmills, Basingstoke, Hampshire RG21 2XS

and London

Companies and representatives

throughout the world

ISBN 978-0-333-46336-9 ISBN 978-1-349-10168-9 (eBook)

DOI 10.1007/978-1-349-10168-9 


\section{The customer}

1 In food service 2

\section{Insight}

2 Styles of table service 4

3 Serving food attractively 6

\section{Method}

4 Preparing for service $\quad 8$

5 When customers arrive 10

6 Serving procedures $1 \quad 12$

7 Serving procedures $2 \quad 14$

8 Serving procedures $3 \quad 16$

9 Serving procedures $4 \quad 18$

10 Serving procedures $5 \quad 20$

11 Serving procedures $6 \quad 22$

12 Serving beverages $1 \quad 24$

13 Serving beverages $2 \quad 26$

14 Serving wine and other drinks 28

15 Serving breakfast 30

16 Billing and taking payment 32

\section{Customercraft}

17 The personal side of service 1

18 The personal side of service 2

\section{Working methods}

19 Working efficiently 38

20 Working safely and hygienically 40 
The publishers would like to thank sincerely the following for their help with the photographs and illustrations used in this book:

Barclays Bank (unit 16)

Catherine Blackie (picture research)

Anthony Blake Photo Library (Capital Hotel) (unit 12)

Brook Hotel, Felixstowe (unit 18, photographer Edward Morgan, shows

Alexandra Boyd who plays Gizzi in the Customercraft video)

Crest Hotels (units 14 and 15)

Gatwick Hilton International (cover, photographer Keith Turnbull)

Grand Metropolitan Retailing (unit 2)

InterCity on Board Services (unit 8)

London Tara Hotel, Kensington (units 4 and 19, photographer Catherine Blackie)

Mecca Leisure Group plc (units 5 and 17)

Thistle Hotels (unit 9)

The White House Restaurant, Regents Park, London (unit 3, photographer Alexia Cross)

The publishers are grateful for the major contribution made by Jennifer Kimber (freelance writer), Mary James and Gill Verstage to the final text of this book. 


\section{The aims of the book}

This book is concerned with the basic procedures involved in serving food and drink to customers at the table. Self-service forms of service-in other words where the customers leave the table to collect the food, or proceed to the table having collected the food-are dealt with in the companion title Servicecraft: Counter Service Workbook. A third title, Servicecraft: Food and Beverage Service, deals comprehensively with the theory and takes many of the issues explored in this Workbook to greater depth.

The emphasis in this Workbook is quite simply that customers' needs come first. This is the emphasis throughout the Mastercraft books and in the supporting videos, particularly Servicecraft 1: Table Service and Customercraft: Keeping the Customers Satisfied. Hotel and catering establishments exist to provide a service to their customers. It makes little difference whether they are in a restaurant, hotel, pub or leisure centre, at school or college, in hospital or an old person's home, or whether the aim of the service is to make a profit (which will only happen if customers come in sufficient numbers) or to meet budgets laid down by a national or local authority.

\section{How the book works}

Servicecraft: Table Service Workbook is designed in units of work laid out on each double page spread. Taking core facts and know-how as its points of departure, each spread moves out towards

- application of skills in the workplace

- interesting and useful detail

- reflective points and reminders.

Every unit includes an activity TO DO, intended to help the reader gain a better understanding and more personal experience of the topics covered.

\section{The structure of the book}

The first unit looks briefly at the customers in food service. The two Insight units introduce the activities common to all styles of service and look at the fundamental questions of food presentation and appearance.

Units 4 to 16 are all concerned with the 'how to', for the aim of the Mastercraft Workbooks is to help the reader in his or her day-to-day activities.

With so many establishments now following a mixed-style of service-one based on meeting the needs of their customers rather than a particular traditional styleit has been felt important to deal in these Method units with the procedures in such a way that they can be applied to a variety of meal situations in a wide variety of establishments. There is no distinction made between the service of lunch or (evening) dinner, for example.

Those readers who are seeking Caterbase food and beverage qualifications for the skills they use in their job on a day-to-day basis, or for new skills they wish to acquire, will therefore find the book of direct assistance.

It will also help students studying for City and Guilds and SCOTVEC qualifications in food and beverage service.

The personal side of service is returned to in the two Customercraft units, 17 and 18 . The final units deal with working efficiently, safely and hygienically. 